\title{
Aktivitas Ekstrak Metanol Daun Akasia (Acacia mangium Wild) Terhadap Perkecambahan Dan Pertumbuhan Maman Ungu (Cleome rutidospermaeD.C) Dan Rumput Grinting (Cynodon dactylon L. Pers)
}

\author{
Sumi $^{1}$, Riza linda ${ }^{1}$, Diah Wulandari Rousdy ${ }^{1}$ \\ Program Studi Biologi, Fakultas MIPA, Universitas Tanjungpura, Jl. Prof. Dr. H. Hadari Nawawi \\ Pontianak, email korespondensi: rsumi21@yahoo.com
}

\begin{abstract}
Acacia (Acacia mangium Wild.) have alelokimia compound that can suppress the growth of the plants that it can be used as bioherbicide. This aimto study determined the concentration of the methanol extract of leaf of acacia capable of inhibit the germination and growth of weed, purple maman (Cleome rutidospermae DC.) and grass grinting(Cynodon dactylon L.). This study use a completely randomized design (CRD) with five replication and five treatment consist of control, concentrationmethanolextract $0.2 ; 0.4 ; 0.6$ and $0.8 \mathrm{~g}$ $\mathrm{ml}^{-1}$. Resultshowed that the methanol extract of leafacacia with a concentration of $0.4 \mathrm{~g} \mathrm{ml}^{-1}$ able to inhibit germinationpurple maman and grass grinting. Concentration of $0.2 \mathrm{~g} \mathrm{ml}^{-1}$ extract acacia can inhibit the growth of plant height, root length, and a decrease in wet weight and dry weight in weed purple maman andgrass grinting
\end{abstract}

Keywords :Acacia mangium, Cleome rutidospermae, Cynodon dactylon, Germination, Growth

\section{PENDAHULUAN}

Rumput grinting (Cynodondactylon) merupakan jenis rumput-rumputan berdaun sempit dan merupakan rumput yang memiliki kemampuan bertahan hidup yang lebih dibandingkan jenis rumput lain seperti rumput tekidan rumput gajah. Rumput ini tumbuh dengan baik pada musim semi dapat bertahan di lahan yang tandus dalam musim kemarau walaupun pertumbuhan daunnya kerdil (Jayadi,1991). Maman ungu (Cleome rutidospermae) merupakan gulma yang tumbuh di berbagai tempat.Memiliki biji yang banyak dan termasuk gulma berdaun lebar yang memiliki permukaan daun yang luas dan perakaran yang dangkal (Pebriani et al., 2013).

Wijaya et al. (2011) menyatakan beberapa gulma seperti Dactyloctenium aegyptium, Borreria alata, Cleome rutidospermae dan $C$. dactylon merupakan gulma yang menjadi masalah utama di perkebunan tebu di Lampung. Gulrma maman ungu dan rumput grinting mampu bertahan hidup meski telah diaplikasikan herbisida pratumbuh seperti Ametrin, Diuron dan 2,4 D dengan dosis dan perlakuan yang berbeda-beda.

Pengendalian gulma menggunakan herbisida sintetis saat ini lebih banyak diminati karena efektivitasnya yang cepat terlihat, tetapi penggunaan herbisida sintetis dalam jangka waktu yang panjang akan mempengaruhi kondisi tanah dan menyebabkan pencemaran lingkungan (Syakir et al., 2008).
Pengendalian gulma yang ramah lingkungan dapat dilakukan dengan cara pemanfaatan gulma melalui senyawa alelokimia tumbuhan yang bersifat bioherbisida (herbisida alami). Efek dari bioherbisida ini relatif tidak menimbulkan residu pada tanaman budidaya sehingga dijadikan alternatif pengendalian (Rahayu, 2001).

Acacia mangium merupakan tumbuhan yang memiliki potensi senyawa alelokimia, yaitu alkaloid, flavonoid, fenol, glikosida, saponin, steroid, tanin, dan terpenoid (Joseph et al., 2016). Menurut Oyun (2006) daun akasia mengandung golongan senyawa fenolik antara lain tanin, dan flavonoid, yang mampu menghambat perkecambahan dan pertumbuhan tumbuhan.

Senyawa alelokimia yang terdapat pada daun akasia menghambat perkecambahan dan pertumbuhan dua jenis gulma, Quillaja saponaria Molina dan Helenium aromaticumdengan penurunantertinggi pada konsentrasi 50\% (Aguilera et al., 2015). Ismail et al. (2004) mengatakan bahwa semakin tinggi konsentrasi ekstrak, maka penghambatan perkecambahan dan pertumbuhan tanaman akan semakin tinggi. Informasi penggunaan senyawa alelokimia sebagai bioherbisida pada akasia dalam menghambat pertumbuhan gulma lain belum banyak dilaporkan. Oleh karena itu, maka penelitian tentang potensi ekstrak metanol daun akasia sebagai bioherbisida pengendali gulma rumput grinting dan maman ungu perlu dilakukan 


\section{BAHAN DAN METODE}

\section{Waktu dan Tempat Penelitian}

Penelitian ini dilaksanakan selama 4 bulan mulai dari bulan Desember sampai bulan Maret 2018. Penelitian uji perkecambahan dan pertumbuhan di lakukan di Laboratorium dan Rumah Kasa Jurusan Biologi Fakultas Matematika dan Ilmu Pengetahuan Alam. Analisis tanah dilakukan di Laboratorium Kimia dan Kesuburan Tanah Fakultas pertanian sedangkan evaporasi maserat dilakukan di Laboratorium Biokimia Politeknik Negeri Pontianak.

\section{Bahan}

Bahan-bahan yang digunakan dalam penelitian iniadalah akuades, biji gulma maman ungu danrumput grinting, daun akasia, $\mathrm{FeCl}_{3} 1 \%$, methanol teknis, Pereaksi Dragendorff, Pereaksi Liebermann-Burchard, Pereaksi Wayer, pereaksi Wagner, Serium Sulfat, dan tanah gambut.

\section{Rancangan Penelitian}

Penelitian menggunakan Rancangan Acak lengkap (RAL) untuk masing- masing jenis gulma uji yaitu gulma maman ungu dan rumput grinting dan Konsentrasi ekstrak daun akasia yang digunakan untuk masing-masing jenis gulma uji yaitu $\mathrm{K} 0=0 \mathrm{~g}$ $\mathrm{ml}^{-1}, \mathrm{~K} 1=0,2 \mathrm{~g} \mathrm{ml}^{-1}, \mathrm{~K} 2=0,4 \mathrm{~g} \mathrm{ml}^{-1}, \mathrm{~K} 3=0,6 \mathrm{~g} \mathrm{ml}^{-1}$ dan $\mathrm{K}=0,8 \mathrm{~g} \mathrm{ml}^{-1}$. Masing masing perlakuan diulang lima kali sehingga diperoleh 25 unit percobaan untuk setiap jenis gulma.

\section{Prosedur Kerja}

\section{Persiapan Media Tanam}

Media tanam yang digunakan pada penelitian ini adalah tanah gambut.Tanah gambut yang digunakan dikeringanginkan dan diayak terlebih dahulu, kemudian tanah gambut sebanyak $1 / 2 \mathrm{~kg}$ dimasukan kedalam polybag dengan ukuran polybag $10 \times 15 \mathrm{~cm}$.

\section{Pengambilan Daun Akasia, Biji Gulma Maman Ungu dan Rumput Grinting \\ Daun akasiayang digunakan sebanyak $5 \mathrm{~kg}$ berat basah dan daun yang diambil adalah daun dengan ciri tidak rusak karena hama dan tidak memperlihatkan gejala terserang sakit. Biji gulma maman ungu dan rumput grinting yang digunakan yaitu dari biji yang tua. Dengan ciri tidak rusak karena hama dan tidak memperlihatkan gejala terserang sakit}

\section{Ekstraksi Daun Akasia}

Sampel daun akasiayang telah disiapkan dicuci bersih dan dikeringanginkan selama \pm 2 minggu (tanpa terkena cahaya matahari).Sampel yang sudah kering kemudian dihaluskan dengan dry blender sehingga didapatkan serbuk (berat kering). Selanjutnya dimaserasi dengan pelarut metanol teknis selama $3 \times 24$ jam dilakukan pengadukan setiap hari, pelarut baru diganti jika warna sudah bening. Maserat hasil penyaringan dikumpulkan menjadi satu dan disimpan di dalam toples kaca dan diuapkan dengan vacum rotary evaporator sampai semua ekstrak kental. Ekstrak yang diperoleh disimpan di dalam desikator silika gel (Olayele, 2007).

\section{Analisis Skrining Fitokimia}

Identifikasi senyawa alkaloid dilakukan dengan menambahkan HCL dan pereaksi Mayer, Wagner dan Dragendroff. Jika terdapat endapan putih pada pereaksi mayer menunjukan adanya senyawa alkaloid. Jika timbul warna Jingga pada pereaksi Dragendroff menunjukan adanya senyawa alkaloid. Jika timbul warna merah kecoklatan pada pereaksi Wagner menunjukan adanya senyawa alkaloid. Identifikasi senyawa flavonoid dilakukan denganmenggunakan serium sulfat, dan jika timbul warna kuning atau kuning-coklat menunjukkan adanya senyawa flavonoid.Identifikasi fenolik menggunakan pereaksi $\mathrm{FeCl}_{3} 1 \%$. Jika timbul warna hijau kehitaman menunjukan adanya senyawa fenolik. Identifikasi steroid menggunakan pereaksi Liebermann-Buchard, jika timbul warna hijau menunjukan adanya senyawa steroid. Identifikasi terpenoid menggunakan pereaksi LiebermannBuchard, dan jika timbul warna cokat kemerahan menunjukan adanya senyawa terpenoid. Identifikasi saponin menggunakan akuades apabila terbentuk busa stabil maka ekstrak mengandung senyawa saponin (Harbone, 1987).

\section{Uji Perkecambahan Biji Gulma Maman Ungu dan Rumput Grinting}

Penelitian dilakukan pada saat gulma maman ungu dan rumput grinting belum tumbuh (pratumbuh). Biji gulma maman ungu dan rumput grinting sebanyak 10 biji disemai pada setiap polibag sebagai media perkecambahan, kemudian disemprotkan dengan $10 \mathrm{ml}$ larutan ekstrak sesuai perlakuan (Penyemprotan larutan ekstrak dilakukan pada awal pengamatan. Pengamatan perkecambahan diakhiri pada hari ke-10 (Pebriani et al., 2013 )

\section{Uji Pertumbuhan Biji Gulma Maman Ungu danRumput Grinting}

Benih gulma sebanyak 3 biji disemai pada setiap polibag. Setelah 10 hari dipilih 1 gulma yang memiliki ukuran yang sama pada masing-masing 
polibag. Penyemprotan larutan ekstrak sebanyak 10 ml dilakukan sesuai dengan perlakuan yang diberikan pada hari ke-10 dan ke-20 setelah tanam. Pengamatan dihentikan pada hari ke-30 setelah tanam (Pebriani et al., 2013 )

\section{Pengukuran Parameter Lingkungan}

Pengukuran $\mathrm{pH}$ tanah dan kesuburan tanah $(\mathrm{N}, \mathrm{P}$ dan K) dilakukan sebelum tanam pengukuran ini dilakukan di Laboratorium Ilmu Tanah Fakultas Pertanian Universitas Tanjungpura. Pengukuran $\mathrm{pH}$ tanah menggunakan soil tester, suhu udara dan kelembaban udara menggunakan termohigrometer dan dilakukan pada saat tanam.

\section{Parameter Pengamatan}

\section{Parameter Pengamatan Perkecambahan}

Parameter perkecambahan yang diamati meliputi persentase perkecambahan (\%) dan panjang kecambah $(\mathrm{cm})$ gulma maman ungu dan rumput grinting. Pengambilan data dilakukan pada hari ke10 setelah tanam.

\section{Parameter Pengamatan Pertumbuhan}

Parameter pertumbuhan yang diamati meliputi tinggi tanaman $(\mathrm{cm})$, panjang akar $(\mathrm{cm})$, berat basah (g) serta berat kering (g). Pengukuran dilakukan pada akhir pengamatan yaitu pada hari ke-30

\section{Analisis Data}

Data yang diperoleh dianalisis dengan menggunakan Analysis Of Variance (ANOVA). Apabila hasil ANOVA menunjukkan adanya pengaruh nyata antara perlakuan, maka diuji lanjut menggunakan Duncan's Multi Range Test (DMRT) pada taraf 5\%. Pengolahan data statistik dilakukan dengan menggunakan program SPSS 18.

\section{HASIL DAN PEMBAHASAN \\ Hasil}

\section{Analisis skrining fitokimia}

Berdasarkan hasil pengamatan, pada ekstrak metanol daun akasia terdapat kandungan senyawa metabolit sekunder seperti alkaloid, flavonoid, terpenoid, steroid dan fenolik Tabel 1. Hasil Positif uji alkaloid dengan perekasi mayer ditandai dengan endapan berwarna putih, uji alkaloid dengan pereaksi wagner ditandai dengan endapan berwarna coklat, uji alkaloid dengan pereaksi dragendroff ditandai dengan endapan coklat kemerahan. Uji flavonoid ditandai dengan endapan bewarna bewarna kuning kecoklatan, uji terpenoid ditandai dengan endapan coklat kemerahan. Uji steroid ditandai dengan endapan berwarna hijau. Uji fenolik ditandai dengan endapan berwarna hitam.
Hasil skrining fitokimia pada ekstrak metanol daun akasia dapat dilihat pada Tabel 1 .

Tabel 1. Hasil Skrining Fitokimia EkstrakMetanol Daun Akasia

\begin{tabular}{ccc}
\hline Nama Pereaksi & $\begin{array}{c}\text { Senyawa } \\
\text { Metabolit }\end{array}$ & $\begin{array}{c}\text { Hasil } \\
\text { deteksi }\end{array}$ \\
\hline Dragendorff & Alkaloid & $(+++)$ \\
Mayer & Alkaloid & $(+++)$ \\
Wagner & Alkaloid & $(+++)$ \\
Serium Sulfat & Flavonoid & $(+++)$ \\
Lieberman-Burchard & Terpenoid & $(+++)$ \\
Lieberman-Burchard & Steroid & $(++)$ \\
FeCl $1 \%$ & Fenolik & $(+++)$ \\
Air + HCL & Saponin & $(-)$ \\
\hline
\end{tabular}

Keterangan : (-) Tidak ada; (+) sedikit; (+++) banyak

\section{Pengaruh Ekstrak Metanol Daun Akasia terhadap Perkecambahan Biji Gulma Maman Ungu dan Rumput Grinting}

Rerata persentase perkecambahan dan panjang kecambah gulma maman ungu dan rumput grinting dengan pemberian ekstrak metanol daun akasia dapat diihat pada Tabel 2.

Tabel 2. Rerata Persentase Perkecambahan dan panjang Kecambah Gulma Maman Ungu dan Rumput Grinting dengan Pemberian Ekstrak Metanol Daun Akasia pada 30 (HST)

Maman Ungu Rumput Grinting

\begin{tabular}{ccccc}
\hline KE & PP $(\%)$ & PK $(\mathrm{cm})$ & PP $(\%)$ & PK $(\mathrm{cm})$ \\
K0 & $100 \pm 0,00^{\mathrm{a}}$ & $5,34 \pm 0,21^{\mathrm{a}}$ & $100 \pm 0,00^{\mathrm{a}}$ & $3,39 \pm 0,28^{\mathrm{a}}$ \\
K1 & $58 \pm 10,95^{\mathrm{b}}$ & $3,13 \pm 0,38^{\mathrm{b}}$ & $68 \pm 10,95^{\mathrm{b}}$ & $2,45 \pm 0,27^{\mathrm{b}}$ \\
K2 & $30 \pm 7,07^{\mathrm{c}}$ & $1,26 \pm 0,23^{\mathrm{c}}$ & $48 \pm 4,47^{\mathrm{c}}$ & $1,68 \pm 0,20^{\mathrm{c}}$ \\
K3 & $8 \pm 8,36^{\mathrm{d}}$ & $0,26 \pm 0,28^{\mathrm{d}}$ & $10 \pm 12,24^{\mathrm{d}}$ & $0,22 \pm 0,23^{\mathrm{d}}$ \\
$\mathrm{K} 4$ & $0 \pm 0,00^{\mathrm{d}}$ & $0 \pm 0,00^{\mathrm{d}}$ & $0 \pm 0,00^{\mathrm{d}}$ & $0 \pm 0,00^{\mathrm{d}}$ \\
\hline
\end{tabular}

Keterangan : Angka-angka pada kolom yang diikuti huruf yang tidak sama menunjukkan pengaruh berbeda nyata menurut uji Duncan pada signifikasi 5\%. Konsentrasi ekstrak (KE), Kontrol (KO), Konsentrasi 0,2 $\mathrm{g} \mathrm{ml}^{-1}$ (K1), Konsentrasi 0,4 $\mathrm{g} \mathrm{ml}^{-1}(\mathrm{~K} 2)$, Konsentrasi 0,6 $\mathrm{g} \mathrm{ml}^{-1}$ (K3), Konsentrasi 0,8 $\mathrm{g} \mathrm{ml}^{-1}$ (K4), Persentase Perkecambahan (PP) dan Panjang Kecambah (PK).

Hasil analisis varian (ANOVA), perlakuan ekstrak metanol daun akasiaberpengaruh nyata terhadap persentase perkecambahan biji maman ungu $\left(\mathrm{F}_{4}\right.$, $\left.{ }_{24}=173,042, P=0,000\right)$ persentase perkecambahan biji rumput grinting $\left(\mathrm{F}_{4}, 24=146,828 P=0,000\right)$, rerata panjang kecambah maman ungu $\left(\mathrm{F}_{4}, \quad 24\right.$ $=379,539, P=0,000)$, rerata panjang kecambah rumput grinting $\left(\mathrm{F}_{4}, \quad 24=204,767, \quad P=0,000\right.$; ANOVA).Rerata persentase perkecambahan dan panjang kecambah gulma maman ungu dan rumput grinting dengan pemberian ekstrak metanol daun akasia dapat diihat pada (Tabel 2). 
Pengaruh Ekstrak Metanol Daun Akasia Terhadap Pertumbuhan Biji Gulma Maman Ungu Dengan PemberianEkstrak Metanol Daun Akasia

Rerata pertumbuhan gulma maman ungu pada30 HSTdengan pemberian ekstrak metanol daun akasia dapat dilihat pada Tabel3.

Tabel 3. Rerata Hasil pada Parameter Pertumbuhan Gulma Maman Ungu pada 30 HSTdengan Pemberian Ekstrak Metanol Daun Akasia

\begin{tabular}{ccccc}
\hline $\mathrm{K}$ & $\mathrm{TT}(\mathrm{cm})$ & $\mathrm{PA}(\mathrm{cm})$ & $\mathrm{BB}(\mathrm{g})$ & $\mathrm{BK}(\mathrm{g})$ \\
$\mathrm{E}$ & & & & \\
\hline $\mathrm{K} 0$ & $10,4 \pm 0,41$ & $8,09 \pm 0,72$ & $0,585 \pm 0,06$ & $0,038 \pm 0,00$ \\
& $\mathrm{a}$ & $\mathrm{a}$ & $\mathrm{a}$ & $\mathrm{a}$ \\
$\mathrm{K} 1$ & $7,10 \pm 0,47$ & $3,90 \pm 0,47$ & $0,311 \pm 0,03$ & $0,021 \pm 0,00$ \\
& $\mathrm{~b}$ & $\mathrm{~b}$ & $\mathrm{~b}$ & $\mathrm{~b}$ \\
$\mathrm{~K} 2$ & $6,46 \pm 0,46$ & $3,26 \pm 0,37$ & $0,171 \pm 0,02$ & $0,008 \pm 0,00$ \\
& $\mathrm{~b}$ & $\mathrm{~b}$ & $\mathrm{c}$ & $\mathrm{c}$ \\
$\mathrm{K} 3$ & $3,40 \pm 0,78$ & $1,50 \pm 0,62$ & $0,029 \pm 0,00$ & $0,003 \pm 0,00$ \\
& $\mathrm{c}$ & $\mathrm{c}$ & $\mathrm{d}$ & $\mathrm{d}$ \\
$\mathrm{K} 4$ & $0 \pm 0,00^{\mathrm{d}}$ & $0 \pm 0,00^{\mathrm{d}}$ & $0 \pm 0,00^{\mathrm{d}}$ & $0 \pm 0,00^{\mathrm{d}}$ \\
\hline
\end{tabular}

Keterangan : Angka-angka pada kolom yang diikuti huruf yang tidak sama menunjukkan pengaruh berbeda nyata menurut uji Duncan pada signifikasi 5\%. Konsentrasi ekstrak (KE), Kontrol (KO), Konsentrasi 0,2 $\mathrm{g} \mathrm{ml}^{-1}(\mathrm{~K} 1)$, Konsentrasi 0,4 $\mathrm{g} \mathrm{ml}^{-1}$ (K2),Konsentrasi 0,6 $\mathrm{g} \mathrm{ml}^{-1}$ (K3), Konsentrasi0,8g ml-1 (K4), Tinggi Tanaman (TT), Panjang Akar (PA), Berat Basah (BB) dan Berat Kering (BK).

Hasil analisis varian (ANOVA).Perlakuan ekstrak metanol daun akasia berpengaruh nyata terhadap pertumbuhan gulma maman ungu. Tinggi tanaman $\left(\mathrm{F}_{4}, 24=317,263, P=0,000\right)$, panjang akar $\left(\mathrm{F}_{4}, 24=\right.$ $180,823 P=0,000)$, berat basah $\left(\mathrm{F}_{4}, 24=238,087, P\right.$ $=0,002)$ dan berat kering $\left(\mathrm{F}_{4}, 24=156,599 P=0,000\right.$ ANOVA).

Hasil uji lanjut Duncan pada parameter tinggi tanaman, panjang akar, berat basah dan berat kering gulma maman ungu semua perlakuan konsentrasi ekstrak metanol daun akasia (K1, K2, K3, dan K4) menunjukan hasil yang berbeda nyata dengan kontrol, tetapi konsentrasi (K1 dan K2) pada tinggi tanaman dan panjang akar maman ungu menunjukan hasil yang tidak berbeda nyata (Tabel 3).

Pengaruh Ekstrak Metanol Daun Akasia terhadapPertumbuhanBiji Rumput Grinting denganPemberian Ekstrak Metanol Daun Akasia Rerata pertumbuhan gulma rumput grinting pada 30HSTdengan pemberian ekstrak metanol daun akasiadapat dilihat pada Tabel 4.

Hasil analisis varian (ANOVA).Perlakuan ekstrak metanol daun akasia berpengaruh nyata terhadap pertumbuhan gulma rumput grinting.Tinggi rumput $\left(\mathrm{F}_{4}, 24=165,319, P=0,000\right)$, panjang akar $\left(\mathrm{F}_{4}, 24\right.$
$=345,315, P=0,000)$, berat basah $\left(\mathrm{F}_{4}, 24=193,830\right.$ $P=0,000)$, dan berat kering $\mathrm{F}_{4}, 24=79,717, P=$ 0,002 ; ANOVA).

Tabel 4. Rerata Hasil pada Parameter Pertumbuhan Gulma rumput grinting pada 30 HST dengan Pemberian Ekstrak Metanol Daun Akasia

\begin{tabular}{|c|c|c|c|c|}
\hline $\begin{array}{l}\mathrm{K} \\
\mathrm{E}\end{array}$ & $\mathrm{TT}(\mathrm{cm})$ & $\mathrm{PA}(\mathrm{cm})$ & $\mathrm{BB}(\mathrm{g})$ & $\mathrm{BK}(\mathrm{g})$ \\
\hline K0 & $\underset{\mathrm{a}}{5,44 \pm 0,39}$ & $\underset{\mathrm{a}}{4,60 \pm 0,21}$ & $\underset{\mathrm{a}}{0,057 \pm 0,00}$ & $\begin{array}{c}0,0110 \pm 0,00 \\
\mathrm{a}\end{array}$ \\
\hline K1 & $\underset{\mathrm{b}}{4,24 \pm 0,39}$ & $\underset{\mathrm{b}}{2,42 \pm 0,32}$ & $\underset{\mathrm{b}}{0,021 \pm 0,00}$ & $\underset{\mathrm{b}}{0,0063 \pm 0,00}$ \\
\hline $\mathrm{K} 2$ & $\underset{\mathrm{c}}{3,66 \pm 0,36}$ & $\underset{\mathrm{c}}{1,24 \pm 0,20}$ & $\underset{\mathrm{c}}{0,008 \pm 0,00}$ & $\underset{\mathrm{c}}{0,0032 \pm 0,00}$ \\
\hline K3 & $1,60 \pm \underset{\mathrm{d}}{0,51}$ & $0,78 \pm 0,19$ & $\underset{\mathrm{d}}{0,002 \pm 0,00}$ & $\underset{\mathrm{d}}{0,0009 \pm 0,00}$ \\
\hline K4 & $0 \pm 0,00^{\mathrm{e}}$ & $0 \pm 0,00^{\mathrm{e}}$ & $0 \pm 0,00^{\mathrm{d}}$ & $0 \pm 0,00^{\mathrm{d}}$ \\
\hline
\end{tabular}

Keterangan : Angka-angka pada kolom yang diikuti huruf yang tidak sama menunjukkan pengaruh berbeda nyata menurut uji Duncan pada signifikasi 5\%. Konsentrasi ekstrak (KE), Kontrol (KO), Konsentrasi 0,2 $\mathrm{g} \mathrm{ml}^{-1}$ (K1), Konsentrasi 0,4 $\mathrm{g} \mathrm{ml}^{-1}(\mathrm{~K} 2)$, Konsentrasi $0,6 \mathrm{~g} \mathrm{ml}^{-1}(\mathrm{~K} 3)$,Konsentrasi $0,8 \mathrm{~g} \mathrm{ml}^{-1}(\mathrm{~K} 4)$, Tinggi Tanaman (TT), Panjang Akar (PA), Berat Basah (BB) dan Berat Kering (BK).

Hasil uji lanjut Duncan pada parameter tinggi tanaman, panjang akar, berat basah dan berat kering pada rumput grinting pada semua perlakuan konsentrasi (K1, K2, K3 Dan K4) menunjukan hasil yang berbeda nyata terhadap kontrol, sedangkan perlakuan konsentrasi pada parameter berat basah dan berat kering (K3 dan K4) menunjukan hasil yang tidak berbeda nyata.Perlakuan dengan konsentrasi (K1, K2, K3 dan K4) mampu menurunkan semua parameter pertumbuhan gulma rumput grinting. Semakin tinggi konsentasi ekstrak metanol daun akasia penurunan akan semakin menurun.

\section{Pembahasan}

Ekstrak daun akasia dibuat dengan menggunakan pelarut metanol dengan metode maserasi. Metode ekstraksi ini digunakan untuk menghindari rusaknya senyawa kimia yang disebabkan oleh suhu tinggi (Voigt, 1995). Pelarut metanol digunakan dalam proses maserasi karena bersifat universal yang dapat mengikat semua komponen kimia yang terdapat dalam tumbuhan, baik yang bersifat polar, semi-polar, dan non-polar. Maserasi dilakukan selama 3x24 jam, dan tiap 24 jam dilakukan penggantian larutan untuk menghindari penjenuhan.

Berdasarkan hasil skrining fitokimia pada ekstrak metanol daun akasia menunjukan hasil positif untuk uji alkaloid, flavonoid, terpenoid, steroid dan fenolik. Sedangkan uji saponin menunukan hasil 
negatif. Hasil skrining fitokimia ekstrak metanol daun akasia pada penelitian ini berbeda dengan penelitian Joseph et al. (2016) menyatakan bahwa hasil analisis kualitatif metabolit sekunder dari batang, daun, dan bunga akasia mengandung golongan senyawa alkaloid, flavonoid, saponin, terpenoid, tanin, fenol dan steroid, kuinon, glikosida. Sedangkan pada penelitian ini pada daun akasia hanya mengandung senyawa alkaloid, flavonoid, terpenoid, steroid dan fenolik tetapi tidak mengandung senyawa saponin dan glikosida.Perbedaan ini diduga karena beberapa faktor yaitu, metode ekstraksi, ukuran partikel sampel, waktu ekstraksi dan perbandingan sampel dengan pelarut (Harbone, 1987), dan juga bisa dipengaruhi oleh faktor internal seperti genetik dan umur tanaman dan dipengaruhi juga oleh faktor eksternal yaitu klimatik, geografi, hama dan penyakit (Febrianti, 2010).

Perlakuan ekstrak metanol daun akasia pada konsentrasi $0,2 \mathrm{~g} \mathrm{ml}^{-1}$ merupakan konsentrasi terkecil yang dapat menghambat persentase perkecambahan dan panjang kecambah maman ungu dan rumput grinting. Penurunan persentase perkecambahan maman ungu dan rumput grinting menjadi $58 \%$ dan $68 \%$. Konsentrasi $0,4 \mathrm{~g} \mathrm{ml}^{-1}$ merupakan konsentrasi yang efektif dalam menghambat perkecambahan biji gulma maman ungu dan rumput grinting, karena menghasilkan persentase perkecambahan dibawah $50 \%$ untuk maman ungu sebesar $30 \%$ dan rumput grinting sebesar 48\% (Tabel 1). Riskitavani \& Purwani (2013), menyatakan bahwa senyawa alelokimia yang terkandung di dalam ekstrak dengan persentase perkecambahan dibawah 50\% dapat bekerja lebih optimal dalam proses penghambatan perkecambahan gulma.

Ekstrak metanol daun akasia mengandung beberapa metabolit sekunder yaitu alkaloid, flavonoid, fenolik, steroid, dan terpenoid.Oyun (2006), menyatakan bahwa senyawa alelokimia kelompok fenolik seperti tanin, dan flavonoid yang terdapat pada daun akasia dapat menghambat perkecambahan dan pertumbuhan tanaman.Senyawa fenolik bersifat alelokimia yang dapat menghambat perkecambahan, salah satunya dengan gangguan sintesis hormon (Einhellig, 1995).

Menurut Rice (1995), senyawa alelokimia yang telah bercampur dengan ekstrak yang mengandung alelokimia akan menghambat sintesis hormon seperti asam giberelin (GA). Trenggono (1990), menyatakan bahwa penghambatan sintesis giberelin menyebabkan tidak terjadinya induksi enzim $\alpha$ amilase.Sehingga tidak terjadinya hidrolisis amilum menjadi glukosa pada endosperm di dalam biji sebagai cadangan makanan bagi embrio.

Kemampuan penghambatan ekstrak metanol daun akasia lebih baik pada gulma maman ungu dibanding rumput grinting. Hal ini berdasarkan hasil persentase perkecambahan (Tabel 2 ) diduga dipengaruhi oleh struktur anatomi biji gulma. Biji gulma maman ungu termasuk dalam biji dikotil yang diduga tidak memiliki lapisan aleuron, lapisan yang melindungi endosperm dan embrio.Selain itu biji maman ungu juga tidak memiliki lapisan koleoriza yaitu lapisan yang melindungi radikula dan plumula (Hidayat, 1995). Kondisi ini memudahkan masuknya senyawa alelokimia ekstrak metanol daun akasia kedalam bijisehingga menghambat perkecambahan biji maman ungu.

Hasil penelitian menunjukan bahwa selain dapat menurunkan persentase perkecambahan juga dapat menghambat rerata panjang kecambah maman ungu dan rumput grinting.Panjang kecambah maman ungu dan rumput grinting mengalami penurunan dengan meningkatnya konsentrasi ekstrak yang diberikan (Tabel 2). Konsentrasi $0,4 \mathrm{~g} \mathrm{ml}^{-1}$ merupakan konsentrasi yang dapat menghambat panjang kecambah. Penghambatan panjang kecambah terjadi melalui gangguan proses mitosis yang mengakibatkan terhambatnya pembelahan sel. Hal tersebut sesuai dengan pernyataan Wattimena (1987) bahwa senyawa fenolik dapat menghambat proses mitosis dengan merusak benang-benang spindel di dalam sel pada tahap metafase, akibatnya jumlah sel tidak bertambah.

Perlakuan konsentrasi ekstrak $0,2 \mathrm{~g} \mathrm{ml}^{-1}$ untuk parameter tinggi tanaman panjang akar, berat basah dan berat kering (Tabel 2 dan Tabel 3) menunjukkan hasil yang berbeda nyata dengan kontrol. Konsentrasi $0,2 \mathrm{~g} \mathrm{ml}^{-1}$ ini merupakan konsentrasi terendah yang memiliki kemampuan dalam menghambat pertumbuhan gulma. Kondisi ini menunjukkan bahwa senyawa alelokimia pada konsentrasi $0,2 \mathrm{~g} \mathrm{ml}^{-1}$ sudah mampu menghambat proses-proses fisiologi pada gulma maman ungu dan rumput grinting (Gardner et al., 1991)

Penghambatan pertumbuhan tinggi tanaman dan panjang akar maman ungu dan rumput grinting (Tabel 2 dan Tabel 3 ) diduga disebabkan oleh senyawa alelokimia yang terdapat di dalam ekstrak metanol daun akasia. Adanya senyawa fenolik yang terdapat didalam ekstrak metanol daun akasia dapat 
menyebabkan gangguan pada transportasi auksin dari pucuk ke akar dan gangguan sintesis sitokinin dibagian akar.

Sitokinin berfungsi untuk pembelahan dan diferensiasi sel akar sedagkan auksin merupakan senyawa yang dapat memacu pemanjangan akar (Gardner et al.,1991). Menurut Ardi (1999) hambatan aktivitas hormon oleh senyawa fenolik dapat menyebabkan pembelahan sel pada bagian meristem pucuk dan akar terganggu sehingga menghambat pertumbuhan tinggi tanaman dan panjang akar.

Perlakuan konsentrasi $0,2 \mathrm{~g} \mathrm{ml}^{-1}$ ekstrak metanol daun akasia menunjukan hasil yang berbeda nyata pada berat basah dan berat kering maman ungu dan rumput grinting. Penurunan berat basah dan berat kering tanaman diduga karena senyawa alelokimia yang terdapat di dalam ekstrak metanol daun akasia. Senyawa alelokimia menghambat fungsi fisiologis di dalam jaringan yang menyebabkan terganggunya proses penyerapan nutrisi dan fotosintesis

Penurunan berat basah dan kering tanaman dipengaruhi oleh kandungan air di dalam sel tanaman. Ketersediaan air yang cukup akan mengoptimalkan proses fotosintesis, sehingga menghasilkan asimilat untuk perkembangan tanaman lebih cepat, sehingga berat basah tanaman akan bertambah. Terjadinya gangguan pada pengikatan air, akan menurunkan fungsi sel akar dalam penyerapan ion pada media tanam sehingga pertumbuhan vegetatif tanaman akan terganggu (Sastroutomo,1990).

Hasil penelitian menggunakan ekstrak metanol daun akasia pada konsentrasi $0,8 \quad \mathrm{~g} \mathrm{ml}^{-1}$ menyebabkan kematian pada gulma. Gejala kematian gulma ditandai dengan daun layu dan mengalami kematian. Riskitavani dan Purwani (2013), menyatakan bahwa layu pada tanaman disebabkan adanya kandungan senyawa fenolik yang terdapat di dalam ekstrak metanol daun akasia. Semakin tinggi kandungan senyawa fenolik seperti tanin, dan flavonoid yang terakumulasi di dalam tanah akan bersifat racun yang dapat menjadikan sel-sel tidak elastis dan menghambat transpor ion terlarut melewati membran sel. Hambatan tersebut menyebabkan jumlah ion terlarut pada bagian tanaman tidak merata yang menyebabkan pertumbuhan abnormal pada tumbuhan. Jika hal ini berlangsung terus-menerus dapat menyebabkan kematian pada tumbuhan.
Ekstrak metanol daun akasia pada penelitian ini efektif bekerja pada pascatumbuh dibandingkan pratumbuh.Ekstrak metanol daun akasia pada penelitian ini efektif bekerja pada pascatumbuh dibandingkan pratumbuh. Penghambatan yang paling efektif untuk gulma maman ungu dan rumput grinting adalah saat pasca tumbuh, hal ini dipengaruhi oleh stadia pertumbuhan gulma karena pada saat pasca tumbuh gulma masih muda dan aktivitas enzim pertumbuhan sangat aktif sehingga gulma lebih rentan terhadap herbisida sehingga penyerapan herbisida akan lebih banyak dan akhirnya akan mengakibatkan pertumbuhan gulmamenjadi abnormal. Sedangkan pada saat pratumbuh bekerja dengan cara mematikan biji gulmayang akan berkecambah, tetapi agar merata pada gulma sasaran diperlukan pengolahan tanah yang baik dan tekstur tanah yang gembur dan juga memerlukan banyak pelarut dalam pengaplikasiannya (Barus, 2003).

Kondisi ini dibuktikan dengan perbedaan konsentrasi yang diperlukan untuk menghambat perkecambahan sebesar $0,4 \mathrm{~g} \mathrm{ml}^{-1}$ lebih tinggi dibandingkan konsentrasi yang digunakan untuk menghambat pertumbuhan yaitu sebesar $0,2 \mathrm{~g} \mathrm{ml}^{-1}$. Sjahril dan Syam'un (2011) menyatakan bahwa herbisida berdasarkan aplikasinya terbagi menjadi herbisida pratumbuh dan pascatumbuh.Herbisida pratumbuh diberikan pada gulma yang sedang tumbuh sebagai penyiapan lahan sebelum tanam, sedangkan herbisida pascatumbuh aplikasinya dilakukan pada gulma dan tanaman yang sudah tumbuh. Hal ini sejalan dengan penelitian Apri et al. (2018) menggunakan ekstrak metanol rhizom alang- alang (Imperata cylindrica) menghambat gulma maman ungu pasca tumbuh menggunakan konsentrasi yang lebih tinggi dalam menghambat perkecambahan $0,3 \mathrm{~g} \mathrm{ml}^{-1}$ dibandingkan konsentrasi yang digunakan untuk menghambat pertumbuhan $0,2 \mathrm{~g} \mathrm{ml}^{-1}$.

\section{DAFTAR PUSTAKA}

Aguilera, N, Becerra, J, \& Guedes, Ml, 2015, Allelopathic Effect Of The Invasive Acacia Dealbata Link (Fabaceae) On Two Native Plant Species In South-Central Chile, Jurnal Gayana, Bot 7 vol.72, no. 2, hal. 231-239

Apri, L, Mukarlina, Riza, L, , 2018, Potensi Ekstrak Metanol Rhizom Alang-Alang (Imperata cylindrica (L.) (Beauv) ) Dalam Penghambatan Pertumbuhan Gulma Maman Ungu (Cleome rutidosperma D.C), Jurnal Protobiont, vol. 7, no. 1 , hal. $25-30$ 
Ardi, 1999, Potensi Alelopati Akar Rimpang AlangAlang (Imperata cylindrica ( L.) Beauv Terhadap Mimosa pudica L, Jurnal .Stigma, vol. 7 no.1, hal. 66- 68

Barus, 2003, Pengendalian Gulma Di Perkebunan, Efektivitas Dan Efisiensi Aplikasi Herbisida, Yogyakarta.

Einhellig FA, 1995, Allelopathy: Current Status ang Future Goals. Chapter 1. In: Inderjit, K.M.M Dakshini, and Einhellig, FA, 1995, Acs Symposium Series: Allelopathy Organism,Processes and Aplications. Washington DC, American Chemical Society

Febrianti F, 2010, Kandungan Total Fenol Komponen Bioaktif Dan Aktivitas Antioksidan Buah Pedada (SonerattiaCaseolaris). Skripsi, Bogor, Fakultas Perikanan Dan Ilmu Kelautan

Gardner, FP, Pearce, RB \& Mitchel, RL, 1991, Fisiologi Tanaman Budidaya, Penerjemah Herawati, S., Penerbit UI Press, Jakarta

Hidayat, E.B, 1995, Anatomi Tumbuhan Berbiji, Penerbit ITB, Bandung, Hal. 247-262

Harbone, JB, 1987, Metode Fitokimia Penuntun Cara Modern Menganalisis Tumbuhan, Edisi ke-2, diterjemahkan oleh Kosasih Padmawinata dan Iwang Soedira, ITB Press, Bandung

Ismail, Nan, \& Metali, F, 2014, Allelopathi Effect Of Invasive Acacia mangium On Germination And Growth Of Local Paddy Varieties, Jurnal Of Agronomy, vol.1, no. 13, hal. 158-168

Jayadi, S, 1991, Tanaman Makanan Ternak Tropika, Institut Pertanian Bogor, Bogor

Joseph, H, Zulkapli, MM, Iskandar, H\& Santin, S, 2016, Molluscicidal Activity Of The Plant Acacia Mangium (Willd.) Against The Snail Pomaceae Canaliculata (Lam.), Jurnal Borneo Akedemika, vol. 1, no. 2, hal. 27-33

Olayele, MT, 2007, Cytotoxicity and Antibacterial Activity of Methanolic Ekstract of Hisbiscus sabdariffa, Journal of Medicinal Plants Research, vol. 1, no. 1, hal. 9-13

Oyun, MB, 2006, Allelopathic Potentialities of Gliricidia sepium and Acacia auriculiformis on the Germination and Seedling Vigour of Maize (Zea mays L.) Jurnal Agricultural and Biological Science, vol.1, no. 3, hal. 44-47

Pebriani, Riza ,L, \& Mukarlina, 2013, Potensi Ekstrak Daun Sembung Rambat (Mikania micrantha
H.B.K) Sebagai Bioherbisida terhadap Gulma Maman Ungu (Cleome rutidosperma D.C) dan Rumput Bahia (Paspalum notatum Flugge), Jurnal Protobiont, vol.2, no. 2, hal. 32 - 38

Rahayu, ES, 2001, Potensi Alelopati Lima Kultivar Padi terhadap Gulma Pesaingnya, Dalam, D, Suroto, A, Yunus, E. Purwanto, dan Supriyono (Eds.) Prosiding I Konfrensi Nasional Himpunan Ilmu Gulma Indonesia XV, Surakarta 17 -19 Juli 2001

Rice, E, L, 1995, Allelopathy, Orlando, Academic Press, Inc

Riskitavani, DV \& Purwani, KI, 2013, Studi Potensi Bioherbisida Ekstrak Daun Ketapang (Terminalia catappa) Terhadap Gulma Rumput Teki (Cyperus rotundus), Jurnal Sains Dan Seni Pomits, vol. 2, no. 2 , hal. 59-69

Sjahril, R \& Syam'un, E, 2011, Herbisida dan Aplikasinya, Makasar

Sastroutomo, SS, 1990, Ekologi Gulma, PT Gramedia Pustaka Utama, Jakarta

Syakir, M, Bintoro, MH, Agusta, H \& Hermanto, 2008, Pemanfaatan Limbah Sagu Sebagai Pengendalian Gulma pada Lahan Perdu, Jurnal Littri, vol.14, no. 3, hal. 107 - 112, Balai Penelitan Tanaman Obat dan Aromatik, IPB, Bogor

Trenggono, RM, 1990, Biologi Benih, Institut Pertanian Bogor Press, Bogor

Voigt, R., 1995, Buku Pelajaran Teknologi Farmasi, Diterjemahkan oleh Soendani N.S., UGM Press, Yogyakarta

Wattimena, GA, 1987, Zat Pengatur Tumbuh, PAU Bioteknologi IPB, Bogor

Wijaya, RB, Yudono, P \& Rogomulyo, R, 2011, Uji Efikasi Herbisida Pratumbuh untuk Pengendalian Gulma Pertanaman Tebu (Saccharumofficinarum L.) 